\title{
COMPARATIVE MORPHOLOGY OF Astraea latispina (PHILIPPI, 1844) AND Astraea olfersii (PHILIPPI, 1846) (MOLLUSCA, GASTROPODA, TURBINIDAE)
}

\author{
MONTEIRO, J. C. and COELHO, A. C. S. \\ Malacologia, Departamento de Invertebrados, Museu Nacional, Universidade Federal do Rio de Janeiro, \\ Quinta da Boa Vista, s/nº, São Cristóvão, CEP 20940-040, Rio de Janeiro, RJ, Brazil \\ Correspondence to: Júlio C. Monteiro and Arnaldo C. dos Santos Coelho, Malacologia, \\ Departamento de Invertebrados, Museu Nacional, Universidade Federal do Rio de Janeiro, \\ Quinta da Boa Vista s/nº, São Cristóvão, CEP 20940-040, Rio de Janeiro, RJ, Brazil, \\ e-mail: malacomn@mn.ufrj.br \\ Received September 26, 2000 - Accepted January 8, 2001 - Distributed February 28, 2002
}

(With 21 figures)

\begin{abstract}
The present study examines comparatively the soft parts of turbinids Astraea latispina and Astraea olfersii. The characters of soft parts of these species, in agreement with Trochoidea organization, allow a differencial diagnosis on the cefalic lappets, appendix of eye-stalk, hypobranchial glands, jaws, radulae, and stomach spiral caecum, which information will be helpful in taxonomic studies.
\end{abstract}

Key words: Mollusca, Turbinidae, Astraea, morphology, Brazil.

\section{RESUMO}

\section{Morfologia comparada de Astraea latispina (Philippi, 1844) e Astraea olfersii (Philippi, 1846) (MOLLUSCA, GASTROPODA, TURBINIDAE)}

O presente estudo trata do exame comparativo das partes moles dos turbinídeos Astraea latispina e Astraea olfersii. Os caracteres das partes moles dessas espécies, concordantes com a organização dos Trochoidea, proporcionaram diagnose diferencial quanto aos lóbulos cefálicos, apêndice do pedúnculo ocular, glândulas hipobranquiais, mandíbulas, rádulas e ceco espiral do estômago, fornecendo um número maior de dados que poderão auxiliar em estudos taxonômicos.

Palavras-chave: Mollusca, Turbinidae, Astraea, morfologia, Brasil.

\section{INTRODUCTION}

Astraea latispina (Philippi, 1844) and Astraea olfersii (Philippi, 1846) are species of relatively common occurrence on the Brazilian coast, living essentially on rocks or corals, generally in intertidal areas. This species belong to the Turbinidae Rafinesque family, 1815, characterized by a shell turbiform or trochiform in shape, few whorls, an oval or oblique aperture, and a calcareous operculum inside with a thin corneous layer.

The Trochoidea Superfamily includes the Turbinidae, Trochidae Rafinesque, 1815, and
Skeneidae Clark, 1851, families (Hickman, 1992). The superfamily species show similarities to morphological characters of the soft parts: Risbec (1939) reported that the Trochidae family is close to Turbinidae and, from an anatomical point of view, no reason exists to separate them; he also pointed out that the calcareous operculum of the Turbinidae is what best differentiates it from Trochidae with its corneus operculum, which is also affirmed by Wenz (1938), Dodge (1958), Graham (1965), and Fretter \& Graham (1977). However, anatomical data have proven to be an important tool in Trochoidea studies: Randles 
(1905) used anatomy to corroborate the differences between Gibbula Risso, 1826, and Calliostoma Swainson, 1840, and discussed the validity of Trochocochlea Adams \& Adams, 1854 (at that time, all subgenera of Thochus Linnnaeus, 1758); Fretter \& Graham (1977) used external morphology of head-foot mass to characterize Trochidae subfamilies and many Trochoidea species. Few works on morphological studies of soft parts of Trochoidea treat the Astraea Röding species, 1798.

According to Flores \& Cáceres-de-Talarico (1980), there are ten recent Astraea species distributed on the Atlantic coast of America. Abbott (1958) regarded four of these species as subspecies of "tecta complex": A. tecta americana (Gmelin, 1791), A. t. cubana (Philippi, 1848), A. t. papillata (Potiez \& Michaud, 1838), and A. t. tecta (Solander, 1786) (sic). He pointed out $A$. olfersii (sic) as a possible Brazilian subspecies of the complex. A. tecta (Lightfoot, 1786) was referred to Brazil by Rios (1975) and Leal (1991).

On other species, A. phoebia Röding, 1798, with shell like that of $A$. latispina, was reported for Brazil by Matthews \& Rios (1967), Rios \& Oleiro (1968), Matthews \& Kempf (1970), Rios (1970, 1975, 1985, 1994), Matthews (1978), and Boffi (1979). However, the occurrence of $A$. phoebia and $A$. tecta in Brazil is doubtful and thus a good subject for an ample comparative study with specimens from the Caribbean and Florida areas (Monteiro, 1997). The morphology of soft parts may be a tool to characterize and differenciate it.

In this study, A. latispina and $A$. olfersii are examined and compared based on the morphology of the soft parts, providing new data that can be helpful in taxonomic studies.

\section{MATERIAL AND METHODS}

\section{Material examined}

Deposited in the Malacological Collections: Museu Nacional/Universidade Federal do Rio de Janeiro (MNRJ) and Instituto de Biologia, Universidade Federal do Rio de Janeiro (IB/UFRJ).

The material referred to as specimens are complete exemplars with shell and soft parts; those referred to here as soft parts are only systems or organs with broken shells.

Astraea latispina (Philippi, 1844): Brazil, Rio de Janeiro State, Cabo Frio, IB/UFRJ 4981, 1 specimen, R. Absalão col., 19/XII/1980; Praia do Forte, MNRJ 7349, 17 specimens, J.C. Monteiro and C.J.F. Costa cols., 10/VIII/1995; Arraial do Cabo, Enseada da Graçainha, 8 soft parts, J.C. Monteiro and C.J.F. Costa cols., 09/VIII/1995; and MNRJ 7351, 11 soft parts, J.C. Monteiro and C.J.F. Costa cols., 13/VIII/1995.

Astraea olfersii (Philippi, 1846): Brazil, Rio de Janeiro State, Cabo Frio, Praia do Forte, MNRJ 7361, 16 specimens, J.C. Monteiro and C.J.F. Costa cols., 10/VIII/1995; Arraial do Cabo, Praia do Pontal, MNRJ 7363, 1 specimen, J.C. Monteiro and C.J.F. Costa cols., 11/VIII/1995; Prainha, MNRJ 2046, 7 specimens, N.D. Santos, J.P. Machado Filho, and M. Gino cols., 10/VII/1956; Enseada da Graçainha, MNRJ 7366, 7 specimens, 1 soft part, J.C. Monteiro and C.J.F. Costa cols., 09/VIII/1995; MNRJ 7365, 6 soft parts, J.C. Monteiro and C.J.F. Costa, 13/VIII/1995; Praia do Forno, MNRJ 7369, 13 specimens and 4 soft parts, J.C. Monterio and C.J.F. Costa cols., 08/VIII/1995; and MNRJ 7370, 6 specimens, J.C. Monteiro col., 19/VII/1996.

\section{Methods}

The specimens for anatomic study were collected manually from the rocky shores of Rio de Janeiro State, Brazil, mainly in low-tide periods. They were anaesthetized based on Castro (1990): magnesium chloride diluted in a recipient with sea water, to which additional amounts were added from time to time, increasing the concentration, adjusted by adding menthol crystals.

The soft parts were removed with tweezers or by breaking the shell with a small vise and preserved in alcohol at $70^{\circ} \mathrm{GL}$. Radulae were prepared based on Jurberg (1964); they were too thick to be prepared on permanent slides, so were kept in glycerol. They were then dissected and drawn under a WILD M5 stereoscopic magnifying glass with camera lucida connected, and again under a WILD M20 microscope with camera lucida connected. 


\section{Abbreviations}

\begin{tabular}{|l|l}
\hline a: anus & mt: marginal teeth \\
ab: aperture of buccal pouch & nl: nephrostome of left kidney \\
ae: appendix of eye-stalk & nr: nephrostome of right kidney \\
al: anterior lobe of right kidney & oe: oesophagus \\
as: aperture of salivary gland & op: oesophageal pouch \\
at: aperture of triangular chamber & os: osphradium \\
av: afferent branchial vessel & p: pericardium \\
cl: cephalic lappets & pl: posterior lobe of right kidney \\
cn: ctenidium & ps: papillary sac \\
ct: central tooth & r: rectum \\
dg: digestive gland & ra: radula \\
e: eye & rh: right hypobranchial gland \\
es: eye-stalk & rp: right pallial vein \\
ev: efferent branchial vessel & rs: radular sac \\
g: gonad & s: snout \\
gn: gonoduct & sc: spiral caecum \\
i: intestine & sg: salivary gland \\
j: jaws & sl: scroll-like tube \\
l: lip & st: stomach \\
lh: left hypobranchial gland & t: cephalic tentacle \\
lt: lateral teeth & tf: triangular flap \\
m: mouth & tp: transverse pallial vein \\
& u: ureter \\
\hline
\end{tabular}

\section{RESULTS}

\section{Astraea latispina (Philippi, 1844)}

Trochus latispina Philippi, 1844: 90, tab. 3, fig. 2. Trochus latispina Philippi, 1844: Philippi, 1846:

129; Reeve, 1861: pl. 8, sp. 40, figs. a-b. Astralium latispina Philippi, 1844: Pilsbry, 1888:

223, pl. 63, figs. 21 e 22; Dall, 1893: 112. Astraea latispina (Philippi, 1844): Lange-de-

Morretes, 1949: 61; Gofferjé, 1950: 231; Buckup \& Buckup, 1957: 21; Rios, 1970: 29, pl. 6; 1975: 29, pl, 8, fig. 90; 1985: 26, pl. 11, fig. 106; 1994: 42, pl. 13, fig. 142; Flores \& Cáceres-de-Talarico, 1980: 100; Calvo, 1987: 71.

Astraea phoebia Röding, 1798: 79: Matthews \& Rios, 1967: 67; Rios \& Oleiro, 1968: 10; Matthews \& Kempf, 1970: 19; Rios, 1970:
29, 1975: 29, pl. 7, fig. 88, 1985: 26, pl. 11, fig. 108, 1994: 41, pl. 14, fig. 144; Matthews, 1978: 21; Boffi, 1979: 19, figs. 42-45.

Astraea foebia Roding, 1798 err. pro phoebia: Oliveira et al., 1981: 66.

Astraea (Astralium) brevispina (Lamarck, 1822): Haas, 1953: 204.

\section{Shell (Figs. 1-3)}

Thick, medium size, up to $35 \mathrm{~mm}$ in length; rust-brown, pale greenish or yellowish, usually with dark brown irregular bands; whorls flattened to weak convexed, expanding overhanging the sutures; sculptured with oblique plicae and three beaded spiral cords; last whorl carinate with 10 to 14 short triangular spines; aperture oval and oblique; columella arched; base usually flattened, radiately lamellose, with five spiral cords, fourth 
cord more developed, weakly depressed between it and the edge; umbilicus absent but present in young shell, umbilical area depressed and greenish or yellowish.

\section{Operculum (Fig. 4)}

Oval, outside white, thick, convex, smooth, with a wide rib; inside flat, dark brown, paucispiral, submarginal nucleus.
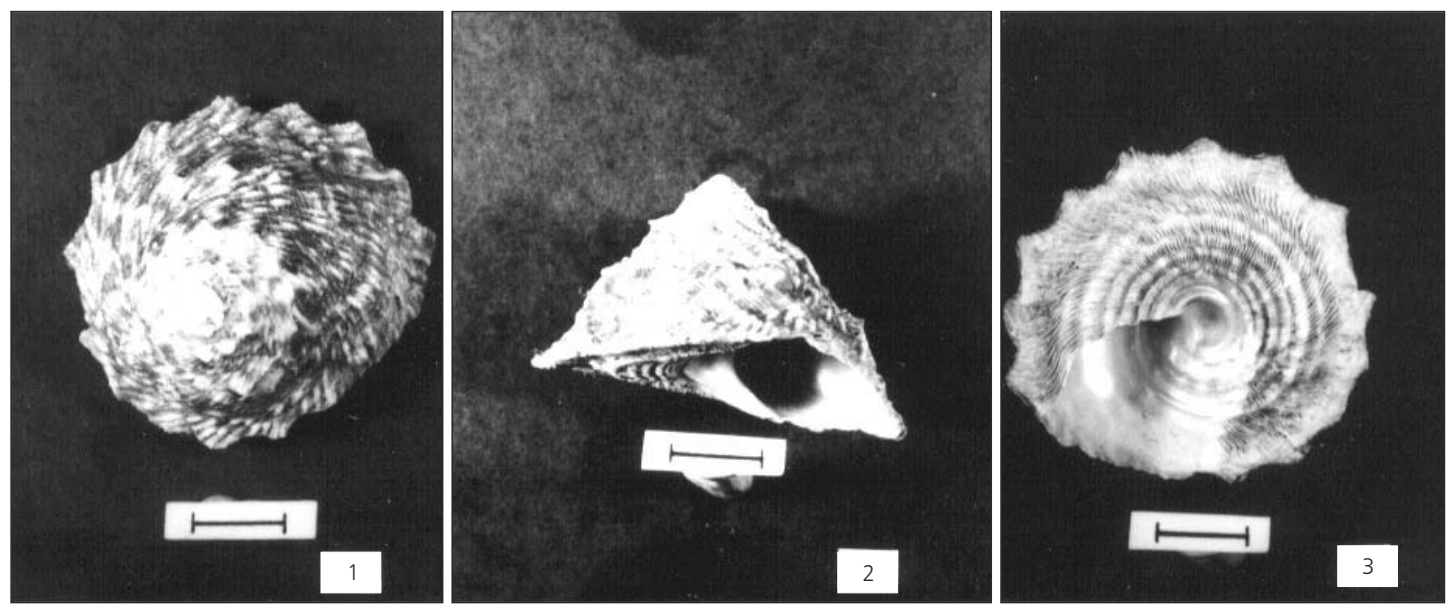

Figs. 1-3 - Shell of Astraea latispina. Scale: $10 \mathrm{~mm}$.

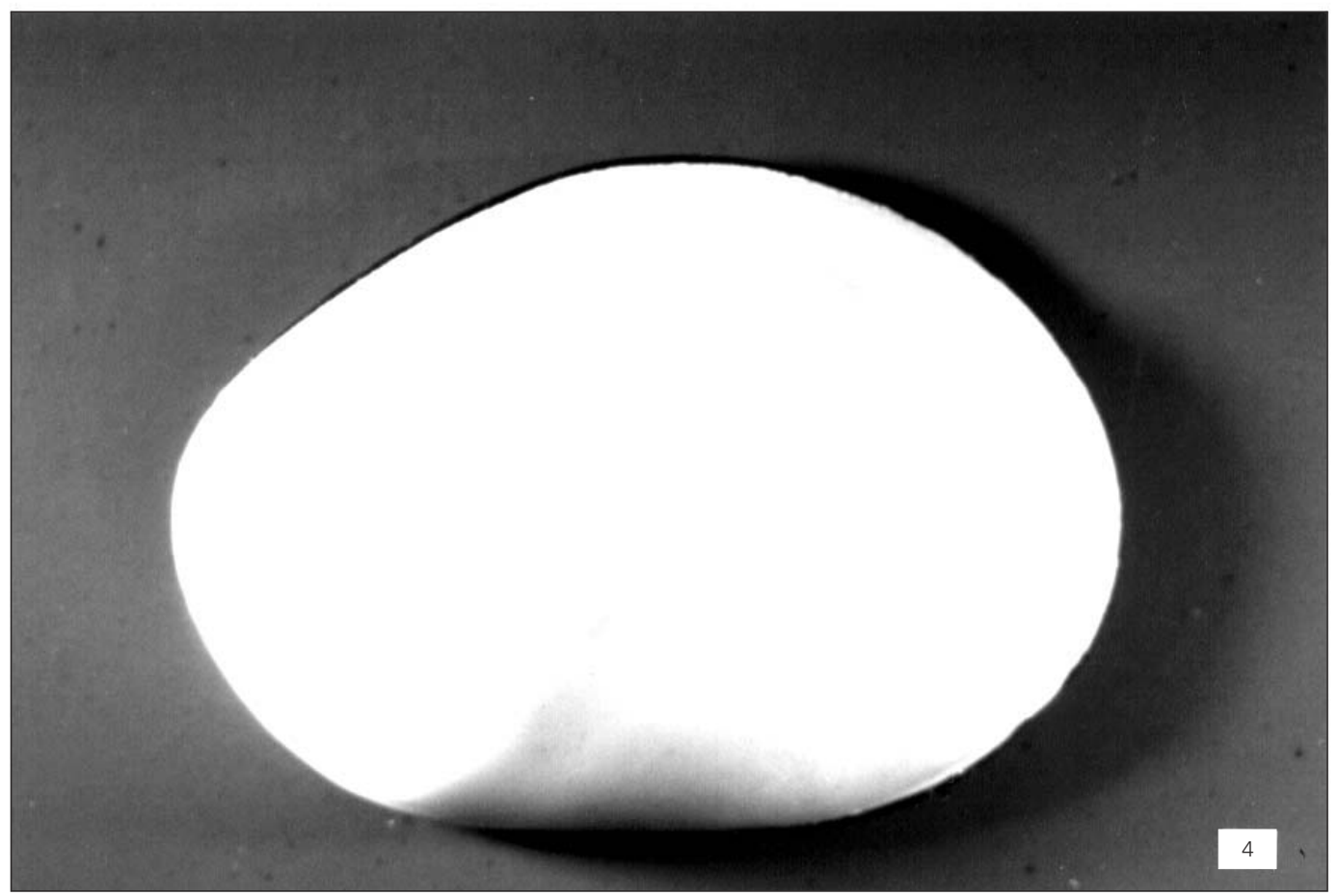

Fig. 4 - Opercullum of Astraea latispina. Dorsal view. Dimention: 16/11.5 mm. 


\section{External morphology of head-foot mass}

Color brown to rust-brown, with light or dark spots over entire surface. Head broad. Short snout, non-extensive. Mouth middle ventral surrounded by lip folds and with a scroll-like tube on right extending to below the eye-stalk. Three pairs of cephalic appendixes: cephalic lappets, cephalic tentacles, and eye-stalks. Cephalic inner lappets, weakly pigmented, rounded, borders with short fringes, underside without middle fold or tenuous. Cephalic tentacles long, cylindrical, extensive, with brown transversal bands. Eye-stalks developed, more external than other cephalic appendixes, external surface weakly carinated, dark eye at the tip. Small appendix under the right eye-stalk (Fig. 5). Foot medium-large, ovate, with papillae, light and smooth sole with medium longitudinal shallow furrow, operculum partially covered by a smooth integument. Epipodial lobes on the upper side of foot, undulated outline, following four epipodial tentacles around the operculum; first epipodial tentacle longer; following ones graduatedly smaller, each with a small appendix at the base.

\section{Pallial cavity (Fig. 7)}

Extended from mantle edge to pericardium as posterior limit. Edge slightly fringed or wavy. Pallial complex at the roof of cavity with ctenidium on the left and rectum on the right. Ctenidium bipectinate with free anterior extremity and afferent and efferent septum of ctinidium dividing the cavity into two chambers. Left chamber reduced, bearing half a series of triangular gill lamellae. Right chamber with the other half of gill lamellae and all the remainder of pallial structures. Osfradium small, rounded, at the base of free portion of ctenidium, on efferent side of septum. Left kidney (papillary sac) oval, elongated, posterior end linked to the pericardium, partially covering the rectum. Opposite the rectum (right part) covered by the anterior lobe of the right kidney, which follows in a short ureter, opening at nephrostome situated close to the nephrostome of left kidney. On part not covered by both kidneys, the rectum is slightly arched, surrounded by folded hypobranchial glands. Right hypobranchial gland generally consists of a short fold beside the rectum and another fold, further, bigger, emitting little folds laterally; there may be another fold between them. Left hypobranchial gland, larger, ochre-greenish to purplebrown, placed between the rectum/left kidney and the ctenidium, formed by seven to twelve lamelles, crossed in the middle by the transverse pallial vein.

\section{Digestive system}

Mouth in ventral region of snout. Roof of buccal cavity with pair of chitinous jaws in anterolateral region. Each jaw nearly rectangular shape, anterior region with numerous and compact rodlike pieces, resistent texture, which becomes tenuous on the edges of posterior region; color light-brown to reddish-brown (Fig. 9). Radular apparatus on the floor of buccal cavity formed by radula, radular sac, and buccal mass. Radula and radular sac runs backwards, doubling from right to left above oesophageal pouches; posterior end of radular sac bifurcated. Radula long, yellowish, 74 to 84 rows of teeth with apical cusps (Fig. 10). Radular formula: 67-5-1-5-67, number of marginal teeth vary from 56 to 71 . Central tooth with a long base and an accessory obovate plate. Lateral teeth progressively bigger, fifth lateral tooth is colorless and has apical granulations. First inner marginal teeth robust, with apical cusp very developed, in the outer marginal teeth other cusps are formed; last marginal teeth elongated and without cusps (Fig. 11).

Pair of dorso-lateral salivary glands in anterior portion formed by small light-yellow rodlike bodies, opening into buccal cavity by short ducts, lateral to a pair of dorsal folds (Fig. 12). Each fold with medial aperture to buccal pouch; between them, slit aperture to another chamber; internally, triangular format.

Oesophagus beginning by a triangular flap with apices projected backward; anterior portion larger, formed by a pair of esophageal pouches. Each pouch with a thin wall, internally covered by small papillae, and a wide fold having one of the surfaces covered by transversal lamellae and the other by papillae. The pouchs are medially joined, and joined through by a longitudinal slit. Posteriorly, the esophagus becomes thin, going ventrally to the stomach. Stomach broad, oval, partially covered by digestive gland on the left and ventrally, anterior limit with posterior lobe of right kidney, gonad on the right. Spiral caecum in dorsal posterior portion of stomach, with four and a half to six turns. Digestive gland broad, dark-brown, covering most of the stomach, and going backwards with the gonad. Intestine follows anteriorly to the stomach, going forward dorsal to the esophagus 
and reaching the esophageal pouches, bends on itself, going posterior until the pericardium, where it crosses the ventricle, entering the pallial cavity as the rectum (Fig. 13).
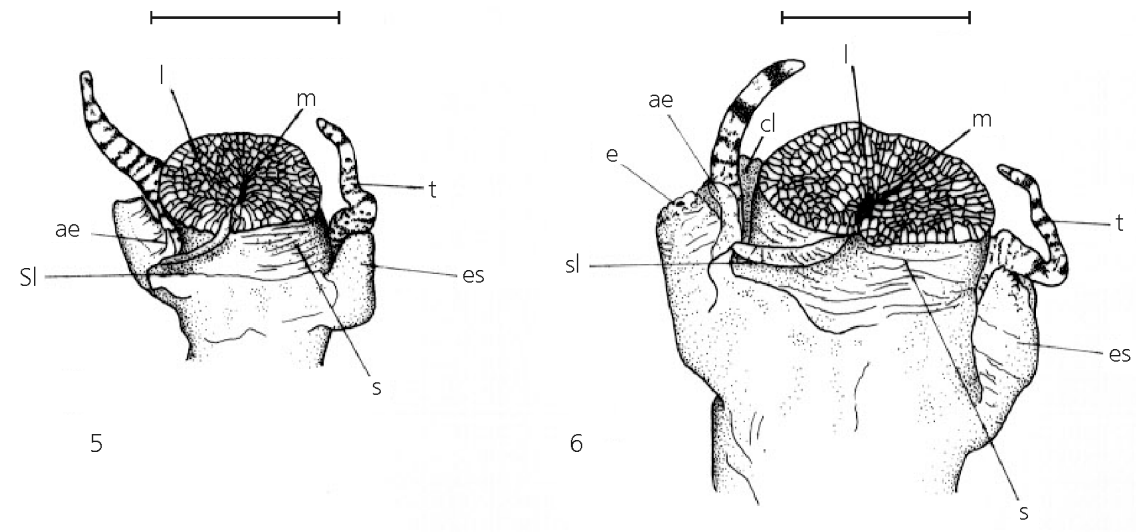

Figs. 5-6 - Ventral view of head. (5) Astraea latispina; (6) Astraea olfersii. Scale: $5 \mathrm{~mm}$.
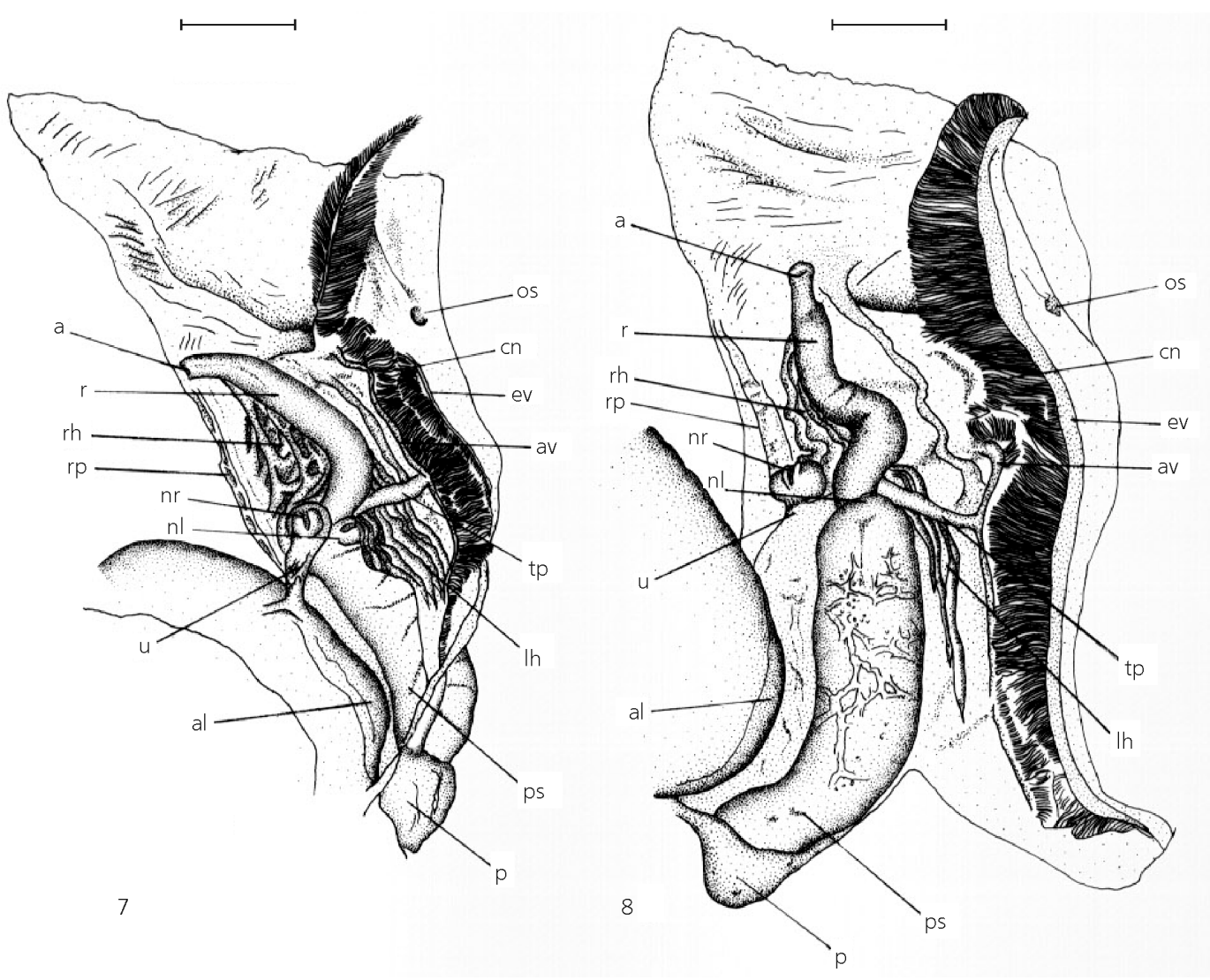

Figs. 7-8 - Roof of palial cavity reflected over to right, inner, ventral view. (7) Astraea latispina; (8) Astraea olfersii. Scale: $5 \mathrm{~mm}$. 


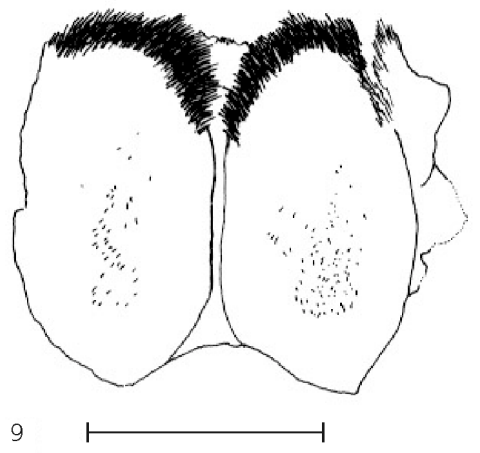

Fig. 9 - Jaws of Astraea latispina. Ventral view. Scale: $2 \mathrm{~mm}$.
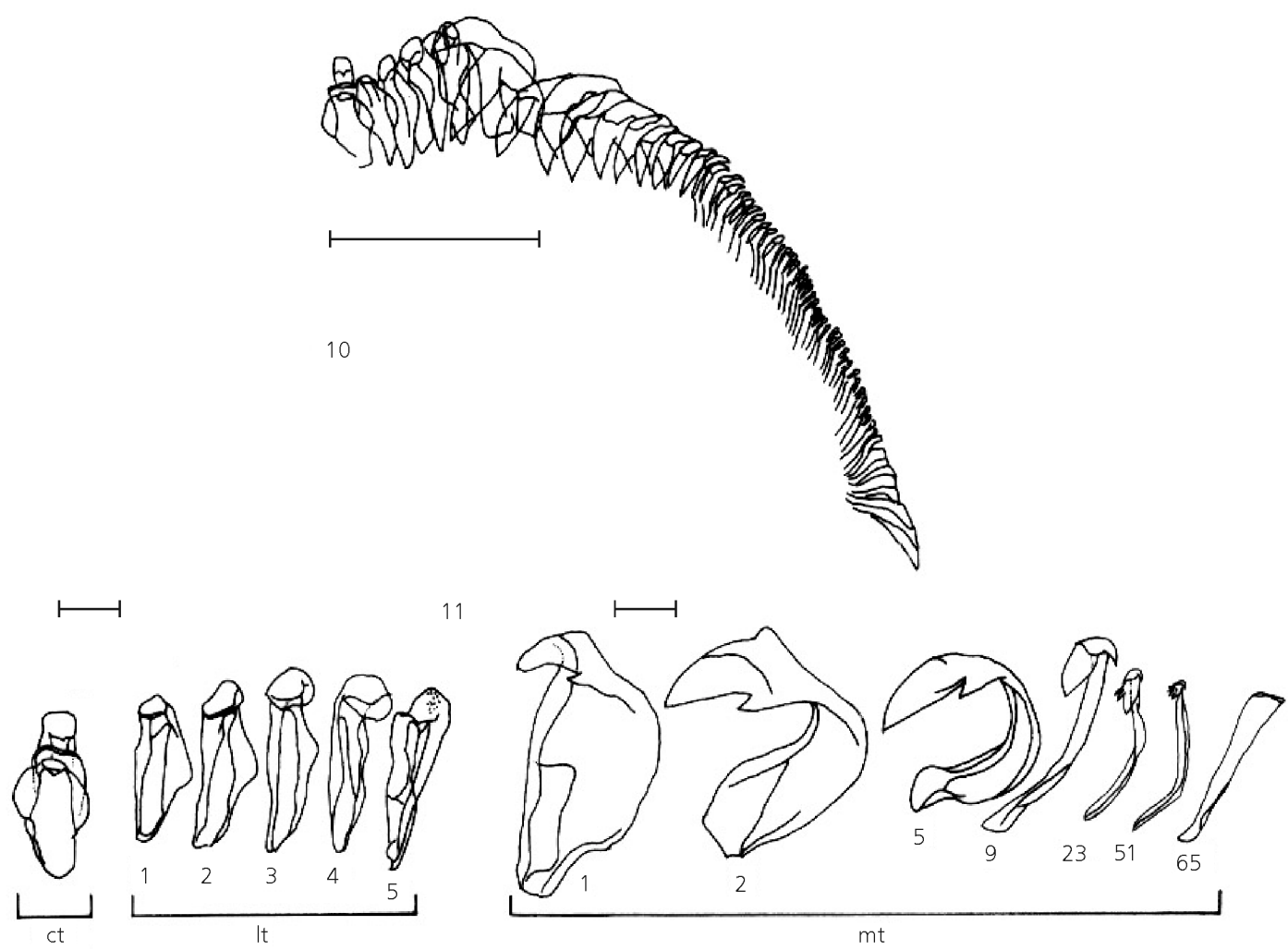

Figs. 10-11 - Radula of Astraea latispina: (10) half row of radula; scale: $0.5 \mathrm{~mm}$; (11) central (ct) lateral (lt) and marginal (mt) teeth; scale: $0.1 \mathrm{~mm}$. 


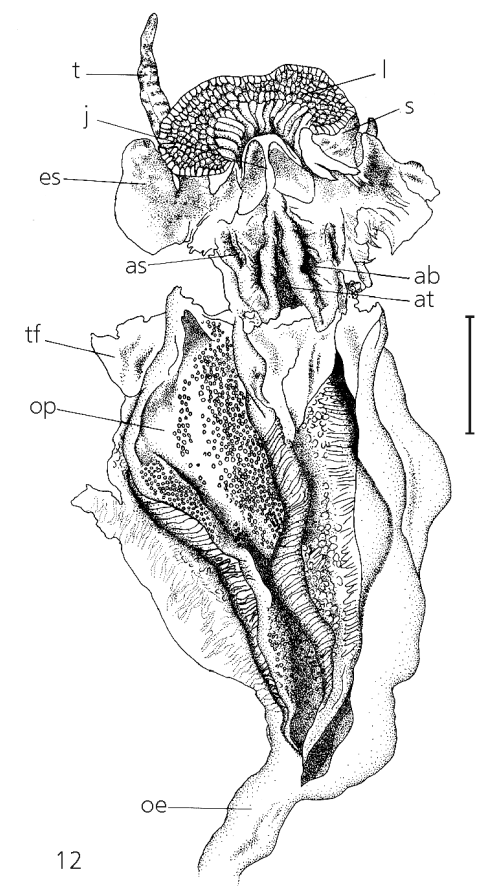

Fig. 12 - Astraea latispina: ventral view of anterior portion of buccal cavity and oesophagus opened longytudinally. Scale: $5 \mathrm{~mm}$.

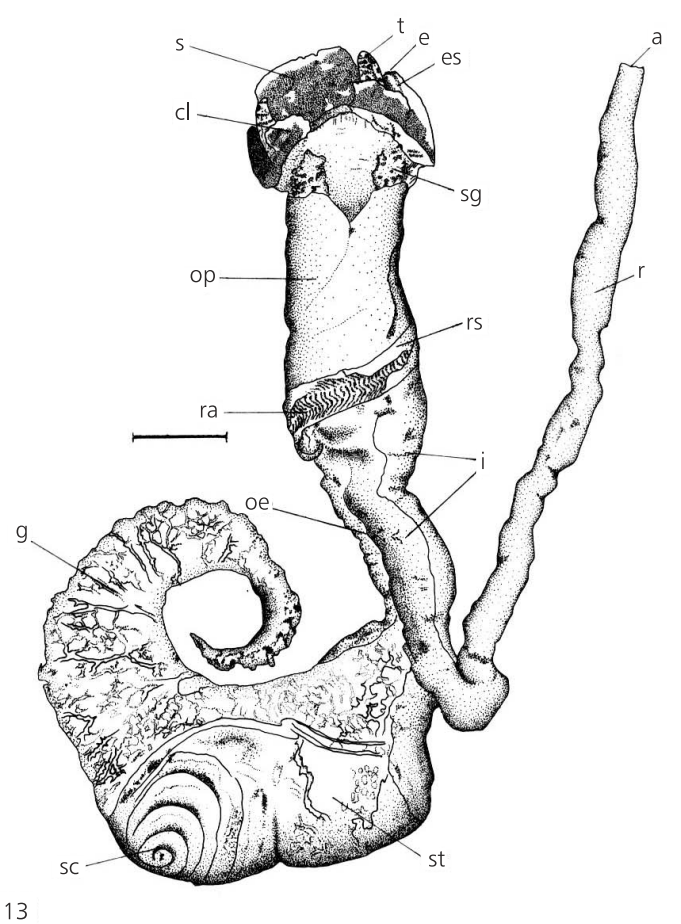

Fig. 13 - Astraea latispina: dorsal view of digestive system dissected. Scale: $5 \mathrm{~mm}$. 


\section{Urogenital system (Fig. 14)}

Gonad lies externally to digestive gland; female gonad olive-green, usually with granular aspect; male gonad cream-pink. Anteriorly reaches the right kidney with which links itself by a short gonoduct of thin walls. Right kidney divided in posterior and anterior lobes. Posterior lobe placed between stomach/ digestive gland and pericardium, becomes larger on the right where it joins the gonad.
A large anterior lobe, adhering to oesophagus and intestine, goes forward in a short ureter into pallial cavity, ending at nephrostome which in the females is freqüently quite enlarged and mucous, and in males is smaller and not glandular; both with slit aperture. Both the anterior and the posterior lobe have glandular and vascular tissue on dorsal surface, and a ventral surface with thin membranous wall, forming a urinary chamber.

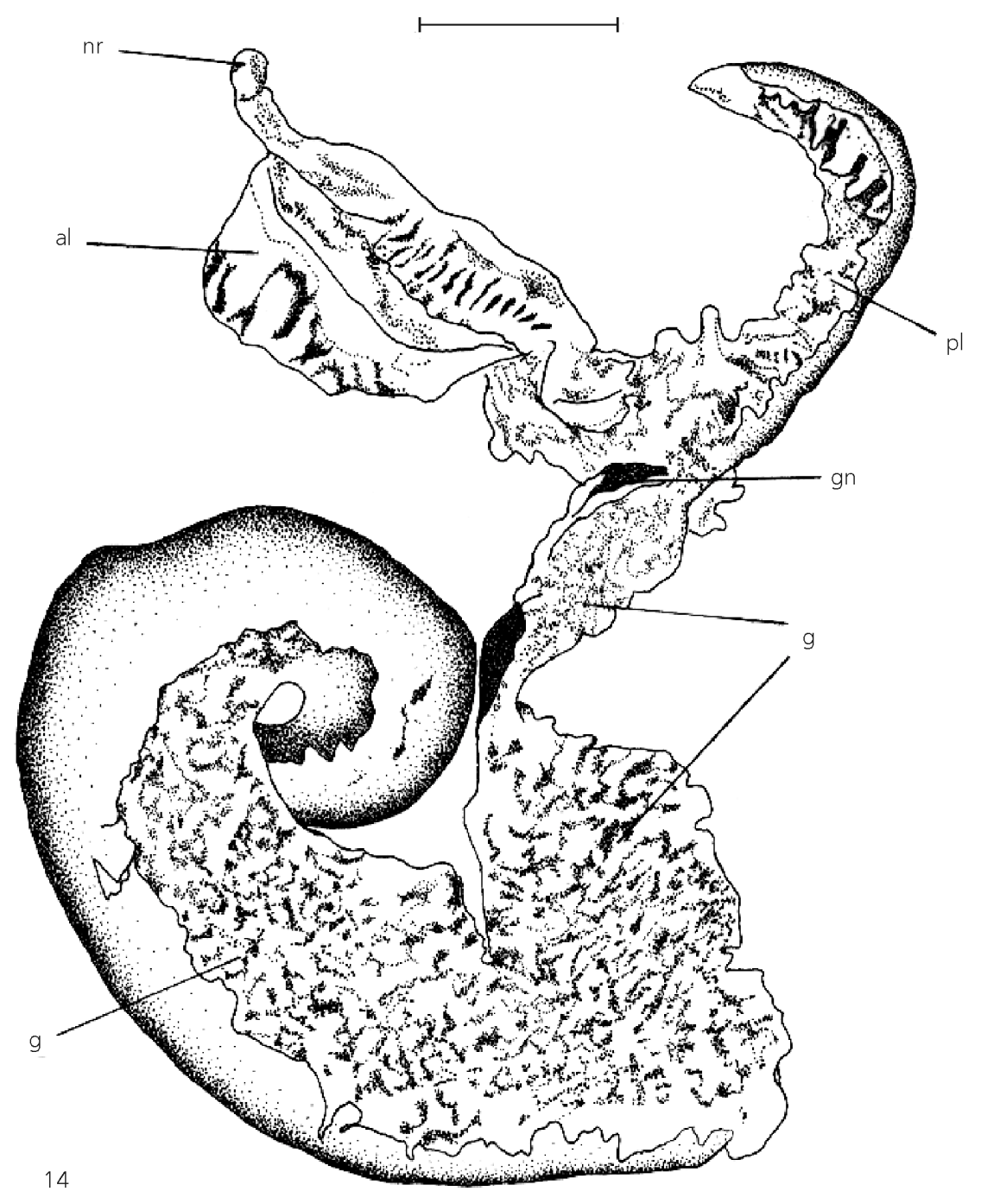

Fig. 14 - Astraea latispina: dorsal view of urogenital system dissected. Scale: $5 \mathrm{~mm}$. 


\section{Astraea olfersii (Philippi, 1846)}

Trochus olfersii Troschel ms.; Philippi, 1846: 126, pl. 22, fig. 1.

Lithopoma olfersii Trosch.: Adams \& Adams, 1858: 401.

Astralium olfersii Troschel, (18 ?): Pilsbry, 1888: 226, pl. 57, figs 47-49, pl. 59, fig. 22-23; Dall, 1893: 112.

Turbo (Calcar) olfersii Troschel: Smith, 1890: 493.

Astraea olfersii (Philippi, 1846): Rios, 1970: 29, pl. 6; Boffi, 1979: 20; Oliveira et al., 1981: 65.

Astraea olfersii 'Troschel' Philippi, 1846: Langede-Morretes, 1949: 61; Gofferjé, 1950: 232; Buckup \& Buckup, 1957: 21.

Astraea olfersii Troschel in Philippi, 1846: Jurberg, 1970: 415.

Astraea olfersii (Philippi, 1846): Lopes \& Alvarenga, 1957: 164; Matthews \& Rios, 1967: 68; Matthews \& Kempf, 1970: 19.

Astraea americana (Gmelin, 1791): Lange-deMorretes, 1949: 61; Matthews \& Rios, 1967: 67.

Astraea tecta (Lightfoot, 1786): Rios, 1975: 29, pl. 7, fig. 89; Leal, 1991: 59, pl. 5, figs. H$\mathrm{K}$.

Astraea tecta olfersii (Philippi, 1846): Calvo, 1987: 73; Rios et al., 1987: 58; Rios, 1985: 26, pl. 11, fig. 107, 1994: 42, pl. 13, fig. 143.

\section{Shell (Figs. 15-17)}

Thick, medium size, up to $45 \mathrm{~mm}$ in length; cream, gray, or light brown; whorls flattened to weak convexed; sculptured with strong oblique ribs, excavated or not on the miedle, periphery of ribs nodulose, rarely pointed; suture generally visible; last whorl with 18 to 24 ribs; aperture oval and oblique; columella arched with 2 tubercles at base; base slightly convex, radiately lamellose, with four spiral cords, rarely with fifth thinner rib; umbilicus absent, depressed umbilical area rounded by a plicate cord.

\section{Operculum (Fig. 18)}

Oval, outside white, thick, convex, granulose, strongly ribbed, with a deep ridge; inside flat, amber to brown, paucispiral, submarginal nucleus.

\section{External morphology of head-foot mass}

Similar to A. latispina. Color dark-brown with light or dark spots all over the surface. Cephalic lappets with a middle fold on the underside. Appendix of the right eye-stalk large, can be as long as the eye-stalk (Fig. 6); short in few specimens. Edge of the left epipodial lobe short digitated fringes.

\section{Pallial cavity (Fig. 8)}

General aspect similar to A. latispina. Right hypobranchial gland has four or five folds parallel to the rectum; the penultimate usually larger than the others; the last linked to the penultimate at the anterior end.

Left hypobranchial gland has three to eight folds, generally five folds posterior to the transverse pallial vein, and three anterior to it.

\section{Digestive system}

The same general pattern as A. latispina. Each jaw has a nearly trapezoidal shape, texture as in A. latispina, anterior end with short rodlike pieces; color light-brown to amber (Fig. 19). Radula long, 75 to 93 rows of teeth (Fig. 20). Radular formula: 70-5-1-5-70, number of marginal teeth vary from 68 to 75 . Central tooth with short base. Lateral teeth approximate the same size of the central tooth; the first to fourth lateral tooth with apical cusp progressively bigger; fifth lateral tooth is colorless and has apical granulations. Marginal teeth series similar to A. latispina (Fig. 21). Spiral caecum of stomach with three to four and a half turns.

\section{Urogenital system}

Same pattern of A. latispina. 

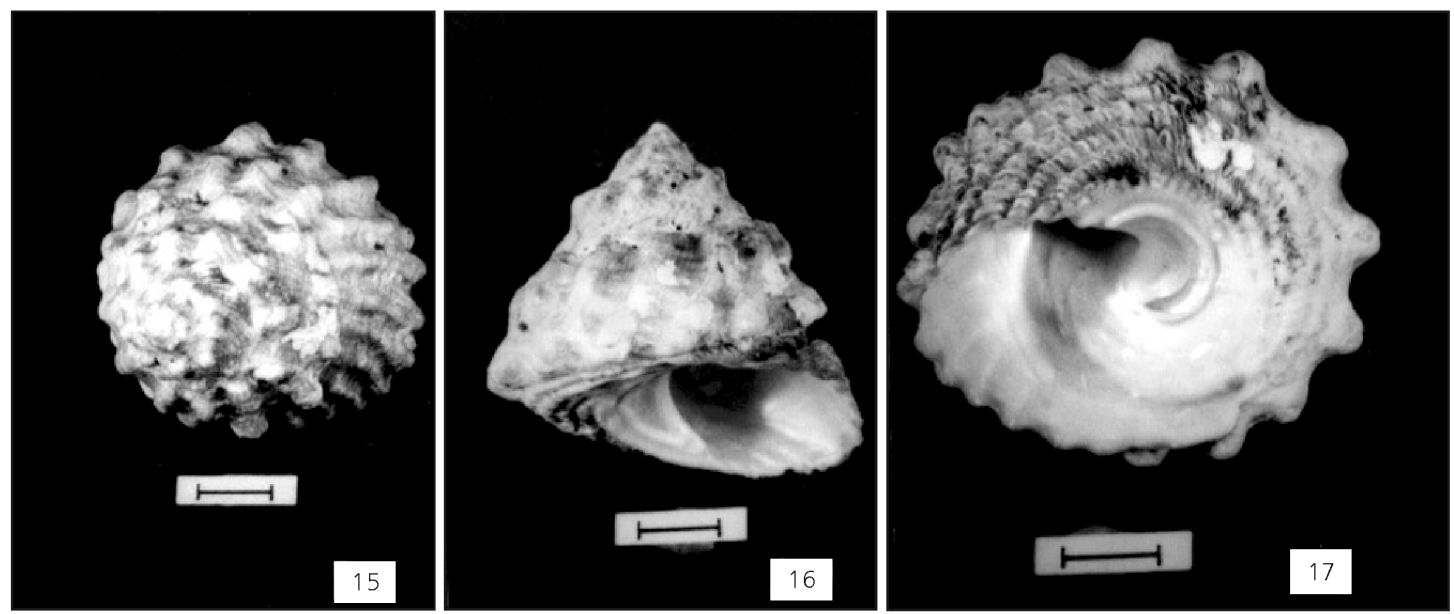

Figs. 15-17 - Shell of Astraea olfersii. Scale: $10 \mathrm{~mm}$.

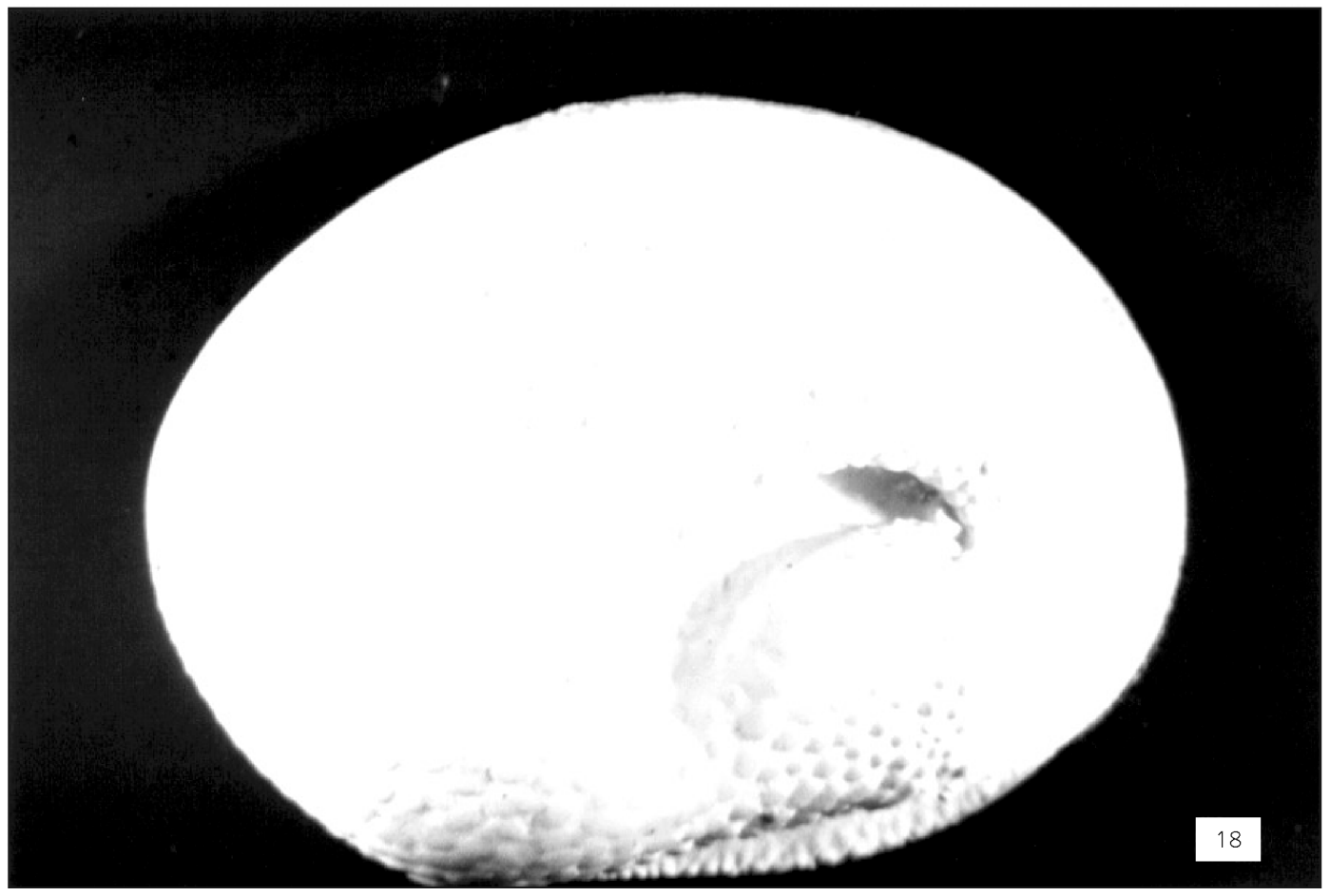

Fig. 18 - Opercullum of Astraea olfersii. Dorsal view. Dimension: 18/13.5 mm. 


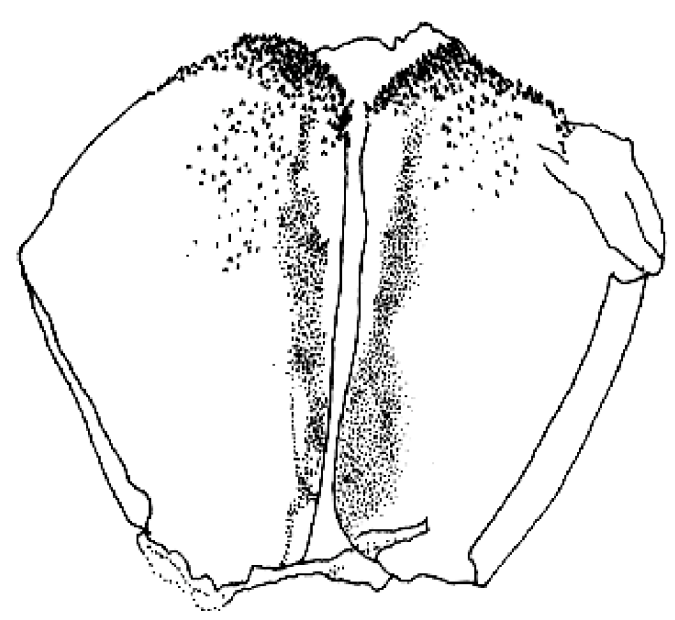

19

Fig. 19 - Jaws of Astraea olfersii. Ventral view. Scale: $2 \mathrm{~mm}$.
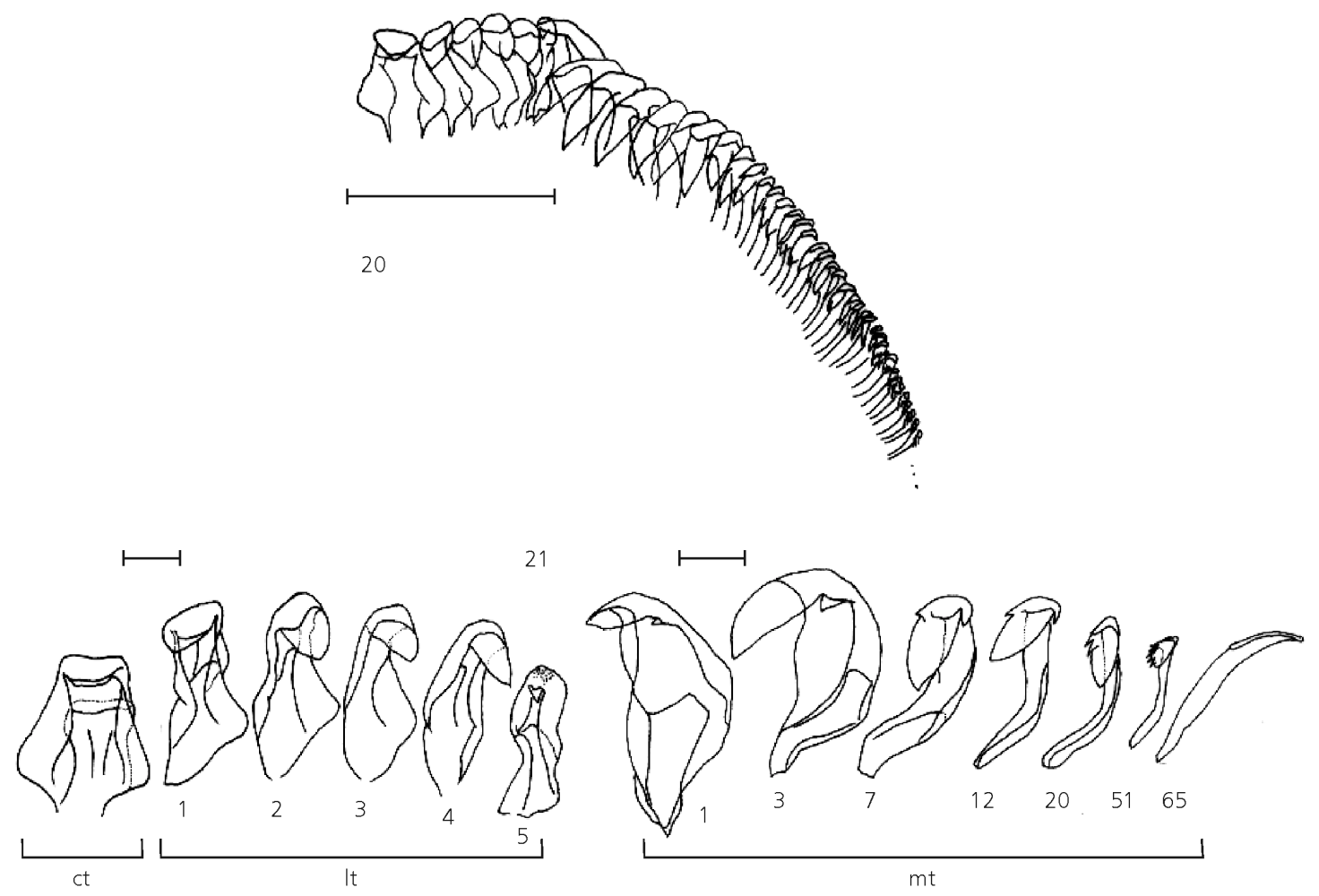

Figs. 20-21 - Radula of Astraea olfersii: (20) half row of radula; scale: $0.5 \mathrm{~mm}$; (21) central (ct) lateral (1t) and marginal (mt) teeth; scale: $0.1 \mathrm{~mm}$. 


\section{DISCUSSION AND CONCLUSIONS}

Differences in color of the head-foot mass have been found among species of the same genus. Fretter \& Graham (1977) found differences in Gibbula cineraria (Linnaeus, 1758), Gibbula umbilicalis (da Costa, 1778), Gibbula magus (Linnaeus, 1758) (Trochidae), and among species of the genera Calliostoma Swainson, 1840 (Trochidae) and Skenea Fleming, 1825 (Skeneidae). A. latispina and $A$. olfersii show similar color of head-foot mass, with light or dark spots over entire surface, but color of A. latispina is lighter than color of $A$. olfersii.

Cephalic lappets are structures that may be reduced or absent in species of Calliostoma, as reported by Randles (1905), Fretter \& Graham (1977), and Sá \& Coelho (1989). According to Risbec (1939), Astraea stellaris (Gmelin, 1791) and Astraea rhodostoma (Lamarck, 1822), both from the Indo-Pacific ocean, have reduced cephalic lappets, whereas in A. latispina and A. olfersii the lappets are developed structures.

The appendix of the right eye-stalk, a common structure in the Trochoidea, can be easily found in $A$. olfersii, while in A. latispina it is reduced. Few specimens of $A$. olfersii have short appendix but never with same size of $A$. latispina. Randles (1905) found this struture in Gibbula cineraria and in G. umbilicalis, but in Gibbula magus and in Monodonta lineata (da Costa, 1778) (Trochidae) it is just a small protuberance; in the genus Calliostoma it is generally absent.

Right and left epipodial lobes are generally asymmetrical in Trochoidea, as reported by Randles (1905) for species of the genus Gibbula (Risso, 1826) with right lobe larger and with a smooth edge, and left lobe smaller, digitated and covered with sensory papillae; nevertheless, in the genus Calliostoma the lobes are symmetrical and smooth. Other authors reported digitate left epipodial lobe and smooth right lobe in different species (Marcus \& Marcus, 1960; Graham, 1965; Righi, 1965; Fretter \& Graham, 1977; Herbert, 1994) or, both lobes smooth, as is the case of genus Calliostoma (Fretter \& Graham, 1977; Sá \& Coelho, 1989). In $A$. latispina both the right and the left lobes generally presented a wavy outline edge, the right freqüently smooth; in $A$. olfersii the left lobe is generally digitated, and the right lobe slightly digitated or undulated.

The hypobranchial gland shows differences in some aspects among species. Clark (1958) associated the size of the hypobranchial gland to rectum position in pallial cavity: species with a straight rectum would have a small right hypobranchial gland, while those with an arcuate rectum would have a medium-to-large right gland. The rectum in both species was shown to be generally arcuate. The right hypobranchial gland in A. latispina has fewer folds than in A. olfersii, but presents ramifications. It is difficult to evaluate in which species the gland is more developed. In both species the rectum is a little arched. The left hypobranchial gland in A. latispina and in $A$. olfersii appears identical, but in some specimens of $A$. latispina this gland is visibly larger than that of $A$. olfersii, also differing in the strong brown-purple coloration.

The digestive system in A. latispina and $A$. olfersii is similar, differing in jaws, radulae, and number of turns of spiral caecum. The pattern is identical to that of the superfamily Trochoidea, as reported for many species by Randles (1905), Risbec (1930, 1939), Marcus \& Marcus (1960), Graham (1965), and Righi (1965).

A. latispina and $A$. olfersii have jaws formed by chitinous rodlike pieces, more visible on the anterior portion. Randles (1905), Risbec (1939), Graham (1965), Sá \& Coelho (1989), and Dekker et al. (1992) observed the same feature in other species of trochoids. However, Risbec (1939) showed jaws with a nacre aspect and without rodlike pieces in Chrysostoma paradoxum (Born, 1778), Astraea stellaris, and A. rhodostoma. A. latispina has an almost rectangularly shaped jaw, and an anterior portion with numerous and compact rodlike pieces while $A$. olfersii has a narrower anterior extremity with shorter rodlike pieces.

The characters of the radulae of $A$. latispina and $A$. olfersii are generally in agreement with the characterizations of Calvo (1987) for these species. They differ as to the central tooth: in $A$. latispina with long base and an accessory obovate plate while in A. olfersii there is a short base without accessory obovate plate, and the lateral teeth differ in size and cusps development. Although the number of marginal teeth in each half row in 
A. latispina and A. olfersii is 67 and 70 respectively, these numbers vary, even among specimens of the same population.

According to Fretter \& Graham (1962), there are few varying characteristics in the prosobranch the stomach to indicate evolutive tendencies: one of these is the gradual disappearence of the spiral caecum, developed in Trochoidea and Zeugobranchia, but vestigial or absent in advanced groups. Another is the dislocation of the aperture of the oesophagus to the anterior portion of the stomach. Randles (1905) reported the spiral caecum of species of Calliostoma distinctly on the outer surface of visceral mass, while in genus Gibbula it is covered by the digestive gland. The spiral caecum in A. latispina has four and a half to six turns; in A. olfersii, three to four and a half turns. Risbec (1939) found in Astraea stellaris and A. rhodostoma five and four turns, respectively. $\mathrm{He}$ also observed an irrregular stomach shape in $A$. stellaris, with aperture of esophagus and intestine in the anterior portion, and the spiral caecum with an anteriorly opened caecum; in A. rhodostoma, esophagus and spiral caecum open anteriorly on posterior region of stomach and intestine. In $A$. latispina and $A$. olfersii esophagus opens ventrally to stomach on median region, as pointed out by authors for most species; intestine opens anteriorly. No anal gland was found in A. latispina and $A$. olfersii. However, a simple type of anal gland in the form of an enlargement in the final rectum portion may occur in some Trochoidea (Fretter \& Graham, 1962). Marcus \& Marcus (1960) reported an anal gland originating in fusion of the typhlosoles and thickening of their epithelium for Tricolia affinis (Robertson, 1958).

According to Perrier (1889), the renal system of trochoids is very similar to that of Haliotis (Linnaeus, 1758); he pointed out that the posterior lobe of the right kidney is uniform in the group while the anterior lobe is quite variable according to the genus. Randles (1905) referred to a small anterior lobe in the right kidney in Gibbula magus, almost an absent in Monodonta lineata but moderately developed in Calliostoma zizyphinus (Linnaeus, 1758); based on Randles (1905) this lobe is quite developed in Turbo (Linnaeus, 1758), and Haliotis and Pleurotomaria (Defrance, 1826); Righi (1965) noted the right lobe as being very developed in Tegula viridula
(Gmelin, 1791). For A. latispina and A. olfersii, the anterior lobe of the right kidney is broad.

In Trochoidea, the gonad generally differs in the sexes by coloration, referred to in males as cream, rosy, or whitish, and in females as lightgreen or olive-green (Perrier, 1889; Randles, 1905; Righi, 1965; Hickman, 1992). According to Hickman (1992), the coloration is not a safe criterion. The best basis for making distinction is the appearance of the ripe gonads, granulate in females and uniform in males. Another way to identify sex is the dilatation of the right nephrostome, generally enlarged in females, as reported by Perrier (1889), Randles (1905), Marcus \& Marcus (1960), Fretter \& Graham (1962), Hyman (1967), Righi (1965), Sá \& Coelho (1989), and Hickman (1992), usually called urogenital papilla. In males there is no dilatation. The connection between green gonad/enlarged nephrostome and cream gonad/small nephrostome was found in the gonads and nephrostomes examined.

Acknowledgments - The authors are specially grateful to Prof. Dr. Norma Campos Salgado and others colleagues from Malacologia (Museu Nacional/Universidade Federal do Rio de Janeiro), and Lia Márcia S. Ribeiro (Museu Nacional/ Universidade Federal do Rio de Janeiro) for translation of the article.

\section{REFERENCES}

ABBOTT, R. T., 1958, The marine mollusks of Grand Cauman Island, British West Indies. Monogr. Acad. Nat. Sci. Philad., 11: 1-138.

ADAMS, H. \& ADAMS, A., 1858, The genera of recent Mollusca arranged according to their organization. John Van Voorst, Paternoster Row, London, $2^{\text {nd }}$ vol., pp. 573660 .

BOFFI, A.V., 1979, Moluscos brasileiros de interêsse médico e econômico. Editora Hucitec, São Paulo, 182p.

BUCKUP, L. \& BUCKUP, E. H., 1957, Catálogo dos moluscos do Museu Rio-Grandense de Ciências Naturais. Iheringia (Zool.), 1: 3-40.

CALVO, I. S., 1987, Rádulas de gastrópodes marinhos brasileiros. Fundação Universidade do Rio Grande, Rio Grande, $201 \mathrm{p}$.

CASTRO, C. B., 1990, Revisão taxonômica dos Octocorallia (Cnidaria, Anthozoa) do litoral sul-americano: da foz do Rio Amazonas à foz do Rio da Prata. Tese de Doutorado, Coordenação de Pós-graduação de Zoologia, Instituto Biologia/USP, São Paulo, 343p.

CLARK, W. C., 1958, Notes on the mantle cavity of some Trochid and Turbinid Gastropoda. Proc. Malac. Soc. Lond., 33: 57-64. 
DALL, W. H., 1893, Additional shells from the coast of Southern Brazil. Nautilus, 6(10): 109-112.

DEKKER, H., MOOLENBEED, R. G. \& DANCE, S. P, 1992, Turbo jonathani, a new turbinid species from the southern coast of Oman (Gastropoda; Turbinidae). J. Conch. Lond., 34: 225-229.

DODGE, H., 1958, A historical review of the mollusks of Linnaeus, Part 6. The genus Trochus of the class Gastropoda. Bull. Am. Mus. Nat. Hist., New York, 116(2): 157-223.

FLORES, C. \& CÁCERES-DE-TALARICO, R., 1980, El genero Astraea Roeding, 1798 (Archaeogastropoda: Turbinidae) en las aguas costeras de Venezuela. Bol. Inst. Oceanogr., 19(1-2): 59-72.

FRETTER, V. \& GRAHAM, A., 1962, British prosobranch molluscs. Ray Society, London, XVI + 755p.

FRETTER, V. \& GRAHAM, A., 1977, The prosobranch molluscs of Britain and Denmark, Part 2 - Trochacea. J. Moll. Stud., London, 3: 39-100.

GOFFERJÉ, C. N., 1950, Contribuição à zoogeografia da malacofauna do litoral do estado do Paraná. Archos Mus. Parana., 8(7): 221-282.

GRAHAM, A., 1965, Observations on the anatomy of some Trochacean gastropods. Bull. Mar. Sci. Gulf Caribb. Coral Gables, 15(1): 202-210.

HAAS, F., 1953, Mollusks from Ilha Grande, Rio de Janeiro, Brazil. Fieldiana, Zool., 34(20): 203-209.

HERBERT, D. G., 1994, Trochus katschyi, the first Indian Ocean record of the genus Osilinus (Mollusca: Gastropoda: Trochidae). J. Zool., 233(3): 345-357.

HICKMAN, C. S., 1992, Reproduction and development of Trochacean Gastropods. Veliger, 35(4): 245-272.

HYMAN, L. H., 1967, The invertebrates. McGraw-Hill Book Company, London.

JURBERG, P., 1964, Sobre Auris bilabiata melanostoma (Moricand, 1836) (Gastropoda, Pulmonata, Bulimulidae) Mem. Inst. Oswaldo Cruz, 62(único): 81-94.

JURBERG, P., 1970, The shell structure of Astraea olfers (Gastropoda: Turbinidae). Malacologia, 10: 415-421.

LANGE-DE-MORRETES, F., 1949, Ensaio de catálogo dos moluscos do Brasil. Archos Mus. Paraná, 7(1): 3-216.

LEAL, J. H., 1991, Marine Prosobranch Gastropods from Oceanic Island off Brazil: species composition and biogeography. Thesis PhD., University of Miami, Miami, $419 \mathrm{p}$.

LOPES, H. S. \& ALVARENGA, M., 1957, Contribuição ao conhecimento dos moluscos da Ilha Fernando de Noronha, Brasil. Bol. Inst. Oceanog., 6(1/2): 157-196.

MARCUS, E. \& MARCUS, E., 1960, On Tricolia affinis cruenta. Bol. Fac. Fil., Ciên. Letr. Univ. S. Paulo (Zoologia), 23: 171-198.
MATTHEWS, H. R., 1978, Les Mollusques du plateau continental de la region du Rio São Francisco N. E. Brasil: etude systematique et tcologique. Theses de Docteur de L'universite, Sciences/L'Universite Pierre et Marie Curie, Paris, 123p.

MATTHEWS, H. R. \& KEMPF, M., 1970, Moluscos marinhos do Norte e Nordeste do Brasil. II - Moluscos do Arquipélago de Fernando de Noronha (com algumas referências ao Atol das Rocas). Arq. Cien. Mar Univ. Fed. Ceará, 10(1): 1-53.

MATTHEWS, H. R. \& RIOS, E. C., 1967, Primeira contribuição ao inventário dos moluscos marinhos do Nordeste Brasileiro. Arq. Est. Biol. Mar. Univ. Fed. Ceará, 7(1): 67-77.

MONTEIRO, J. C., 1997, Estudo sobre as espécies brasileiras de Astraea Röding, 1798 (Mollusca, Gastropoda, Turbinidae). Dissertação de Mestrado, Programa de Pósgraduação de Ciências Biológicas (Zoologia), Museu Nacional/UFRJ, Rio de Janeiro, $X+85 p$.

OLIVEIRA, M. P., REZENDE, G. J. R. \& CASTRO, G. A., 1981, Catálogo dos moluscos da Universidade Federal de Juiz de Fora. UFJF, Juiz de Fora, 620p.

PERRIER, M. R., 1889, Recherches sur l'anatomie et l'histologie du rein des gastéropodes prosobranches. Ann. Sci. nat. Zool., 8: 61-315.

PHILIPPI, R. A., 1844, Abbildungen und Beschreibungen neur oder wenig gekanter Conchylien. Cassel, Drud und Berlag von Theodor Fischer, 1: 77-186, il.

PHILIPPI, R. A., 1846, Die Kreiselschnecken oder Trochoideen. 2 (part 3): 1-372. In: F. H. W. Martini \& J. H. Chemmitz (eds.), Neus Systematisches Conchylien Cabinet, Nuremberg.

PILSBRY, H. A., 1888, Family Turbinidae. In: Tryon Jr., G. W. \& Pilsbry, H. A., Manual of Conchology. Philadelphia, Academy of Natural Sciences of Philadelphia, 10: 1-323.

RANDLES, W. B., 1905, Some observations on the anatomy and affinities of the Trochidae. Qu. J. Micr. Sci N. Ser. 48: 33-78.

REEVE, L. A., 1861, Monograph of the genus Trochus. Conchologia Iconica. L. Reeve \& Co., London, 13 (1862), 2-15.

RIGHI, G., 1965, Sobre Tegula viridula Gmelin. Bol. Fac. Fil., Ciên. Letr. Univ. S. Paulo (Zoologia), 25: 325-390,.

RIOS, E. C., 1970, Coastal brazilian seashells. Fundação Cidade do Rio Grande, Rio Grande, 255p.

RIOS, E. C., 1975, Brazilian marine mollusks iconography. Fundação Universidade do Rio Grande, Rio Grande, 331p.

RIOS, E. C., 1985, Seashells of Brazil. Fundação Universidade do Rio Grande, Museu Oceanográfico, Rio Grande, $329 \mathrm{p}$.

RIOS, E. C., 1994, Seashells of Brazil. Fundação Universidade do Rio Grande, Museu Oceanográfico, $2^{2}$ ed., Rio Grande, 368p. 
RIOS, E. C., CALVO, I. S. \& BARCELLOS, L. J., 1987, Moluscos marinos de la Isla Trinidad. Com. Soc. Malac. Urug., 7(52/53): 57-62.

RIOS, E. C. \& OLEIRO, E. T. A. P., 1968, Estudos malacológicos na Costa Brasileira. Publ. Inst. Pesq. Mar., 31: 1-28.

RISBEC, J., 1930, Étude d'un mollusque nacrier de troque (Trochus niloticus). Faune Colon. Fr., 4(2): 150-189.

RISBEC, J., 1939, Recherches anatomiques sur les Prosobranches de Nouvelle-Calédonie. Deuxième partie (1). Annl. Sci. Nat. Zool., 2(11): 235-298.
SÁ, M. R. \& COELHO, A. C. S., 1989, Aspectos da morfologia interna de Calliostoma (Elmerlinia) jujubinum (Gmelin, 1791) (Mollusca, Gastropoda, Trochidae). Bolm. Zool., 10: 263-271.

SMITH, E. A., 1890, Mollusca. In: H. N. Ridley (ed.), Notes on the zoology of Fernando de Noronha. J. Linn. Soc., 20(124/125): 483-503.

WENZ, W., 1938, Gastropoda 1: Allgemeiner teil und Prosobranchia. In: O. H. Schindewolf (ed.), Handbuch der Palaozoologie, 6(1-3): 1-480. 